\title{
P01.41. Melittin inhibits VEGF-A-induced tumor growth and angiogenesis through blocking VEGFR-2 and COX-2 in allograft tumor model and endothelial cells
}

\author{
J Huh", J Kang, Y Baek, D Choi, D Park, J Lee \\ From International Research Congress on Integrative Medicine and Health 2012 \\ Portland, Oregon, USA. 15-18 May 2012
}

\section{Purpose}

To evaluate the in vivo as well as in vitro anti-angiogenesis effects of melittin, a major polypeptide in bee venom, and to elucidate its molecular mechanisms with a special focus on VEGFR-2 mediated COX-2 and MAPK pathways in VEGF-A-induced Lewis lung cancer (VEGF-A-hm LLC) model and human lymphatic endothelial cells (VEGF-A-HLECs).

\section{Methods}

We investigated the functional specificity of melittin as an angiogenesis inhibitor using VEGF-A-induced in vitro models and an in vivo lung metastasis mouse model.

\section{Results}

Injection of $0.5 \mathrm{mg} / \mathrm{kg}$ and $5 \mathrm{mg} / \mathrm{kg}$ of melittin suppressed tumor growth by $25.30 \%$ and $56.92 \%$, respectively; these results are superior to those obtained for mice treated with the COX-2 inhibitor, NS398. Melittin reduced tumor cell proliferation (PCNA), microvessel density (MVD), expression of cyclooxygenase-2 (COX2), VEGF-A, and VEGFR-2, but did not affect VEGFR-1, in VEGF-A-induced hm LLC tumors. Similarly, the COX-2 inhibitor NS398 significantly inhibited proliferation, MVD, COX-2, VEGF-A, and VEGFR-2 expression in the tumor section, supporting the role of COX-2 in melittin-induced inhibition of angiogenesis. Melittin significantly inhibited VEGF-A-induced proliferation and tube formation in the endothelial cells. Melittin inhibited phosphorylation of ERK 1/2, JNK and p38 MAPK

Kyung Hee University, Seoul, Republic of Korea in a dose-dependent manner in VEGF-A-HLECs. p38 inhibitor SB203580 abolished the down regulation of COX-2 and VEGF-A and anti-proliferative activity induced by melittin.

\section{Conclusion}

These results suggest that melittin suppresses VEGF-Ainduced tumor growth and angiogenesis via VEGFR-2 mediated COX-2 and the MAPK-dependent pathway.

Published: 12 June 2012

doi:10.1186/1472-6882-12-S1-P41

Cite this article as: Huh et al:: P01.41. Melittin inhibits VEGF-A-induced tumor growth and angiogenesis through blocking VEGFR-2 and COX-2 in allograft tumor model and endothelial cells. BMC Complementary and Alternative Medicine 2012 12(Suppl 1):P41.

Submit your next manuscript to BioMed Central and take full advantage of:

- Convenient online submission

- Thorough peer review

- No space constraints or color figure charges

- Immediate publication on acceptance

- Inclusion in PubMed, CAS, Scopus and Google Scholar

- Research which is freely available for redistribution 